\title{
NEW CHALLENGES IN THE UK LEGAL EDUCATION LANDSCAPE: TEF, SQE AND THE LAW TEACHER
}

\author{
MARIBEL CANTO-LÓPEZ \\ Lecturer in Law \\ mic11@le.ac.uk \\ University of Leicester, $U K$
}

\begin{abstract}
:
A recent series of changes in Higher Education in general, and legal education, in particular, are altering the environment in which law teachers in the UK are used to work. This paper will mention two particular initiatives: on the one hand, the Teaching Excellence Framework (TEF) a Government and market focussed scheme to drive up the standard of teaching and to provide information to students about the best provision of teaching. On the other hand, the Solicitors Regulation Authority (SRA) new proposed Solicitors Qualifying Exam (SQE). The SQE is also entangled in market forces, employability and consumer choices, it pretends to end with the inconsistencies in law degrees and trainings offered at the moment; and to help social mobility in the profession. Both initiatives have been received with opposition by many parties that contend their reasons and data are flawed. In any case, both initiatives are affecting law teachers that as a consequence have lately being faced with new demands by students, employers and university managers. We conclude with the assertion that nowadays in the UK many law teachers are confronted with many pressures, numerous unanswered questions and no space to voice their concerns on a rapidly changing legal education landscape.
\end{abstract}

Keywords: UK's legal education, Teaching Excellence Framework (TEF), Solicitors Qualifying Exam (SQE), Marketisation of Higher Education, Students as Consumers, Employability.

\section{Resumen:}

El entorno habitual de los profesores de Derecho en el Reino Unido se ha visto afectado recientemente por una serie de cambios. Estos cambios se concentran tanto en el ámbito general de la educación universitaria como en el ámbito particular de la educación jurídica. Este trabajo se va a centrar en dos iniciativas fundamentales. En primer lugar, TEF, que se refiere al nuevo marco de excelencia en enseñanza universitaria, y que cuenta con el patrocinio del gobierno y de las fuerzas del mercado. Este nuevo marco pretende mejorar el estándar en educación universitaria y al mismo tiempo hacer público aquellas universidades con el estándar más alto. En segundo lugar, nos referiremos al SQE, que es un nuevo examen capacitador para los solicitors (un tipo de abogacía inglesa). El SQE ha sido propuesto por la Autoridad Reguladora de los Solicitors, que dice basarse en las exigencias de empleadores, consumidores y el mercado en general. Con este nuevo examen se pretende homogeneizar los grados de Derecho y los cursos de formación práctica de abogacía, impartidos en diferentes instituciones; buscando acabar con elitismos y ayudar a la movilidad social. Ambas iniciativas has sido recibidas con bastante resistencia por diversos sectores, que REJIE Nueva época: Revista Jurídica de Investigación e Innovación Educativa Núm.18, Junio 2018, pp. 11-30 [En línea] http://www.revistas.uma.es/index.php/rejie 
consideran que tanto las razones aducidas para introducir los cambios como los datos en que se basan son erróneos. En cualquier caso, uno de los sectores mas afectado es el de los profesores de Derecho que actualmente están haciendo frente a las nuevas exigencias de estudiantes, empleadores y altos cargos universitarios. Concluimos afirmando que hoy día en el Reino Unido, muchos profesores de Derecho están barajando en silencio innumerables incógnitas y presiones, sin una plataforma en la que expresar sus preocupaciones, en el ámbito de una educación universitaria y jurídica que está cambiando vertiginosamente a su alrededor.

Palabras Clave: Educacion Juridica en el Reino Unido. Marco de Excelencia en el ambito de la ensenanza universitaria, Examen capacitador para un tipo de abogacia inglesa (solicitor), Comercializacion de los estudios universitarios, Estudiantes como consumidores, Empleabilidad.

Summary: 1. Introduction. 2. The Teaching Excellence Framework. 2.1. TEF and the Students as Consumers. 2.2. TEF and Employability. 2.3. TEF and Teaching. 2.4. TEF and the University Teachers. 3. The Solicitors Qualifying Exam. 3.1. SQE and its Reasons. 3.2 SQE and its Practicalities. 3.3. SQE and its Immediate Reactions. 4. Conclusions. Bibliography.

\section{Introduction.}

Indeed, we all automatically react with an immediate feeling of antagonism to any kind of change. For law teachers in the UK changes keep coming from many fronts, and at this point in time, they are not exactly sure about the consequences, but just feeling ongoing pressures from the market, students, employers and university managers; and staring into the unknown. In this paper we will look at two main initiatives that are affecting the landscape of Higher Education in general, and legal education in particular: the Teaching Excellence Framework (TEF) and the Solicitors Qualification Exam (SQE). Firstly, we will look at TEF a Government initiative that is changing HE and seems to be steered more by market forces than pedagogical ones. Then, we will examine the new proposal of the Solicitors Regulation Authority (SRA): the SQE, a new centralised exam for those wanting to become a Solicitor. ${ }^{1}$ It is too soon to adventure the real weight of TEF or the SQE and which consequences it will really have for law teachers. Undoubtedly, they will. The extent will be down to the kind of University and Law school in which the teachers work. The common thread on this paper, as we will see below, is one in which law teachers have to face changes and demands without much of a say on the on-going transformation of the HE and the legal education landscape.

\section{The Teaching Excellence Framework.}

TEF started being revealed on the Government's paper 'Fulfilling Our Potential: Teaching excellence, Social Mobility and Student Choice' in 2015 (Green Paper). ${ }^{2}$

\footnotetext{
${ }^{1}$ HALL E (2017) "Notes on the SRA report of the consultation on the Solicitors qualifying Exam: "Comment is free, but facts are sacred"' in The Law Teacher Vol 51 No 3, 2017, p. 364

2 DEPARTMENT FOR BUSINESS INNOVATION AND SKILLS, (Green Paper) 2015. 'Fulfilling our potential: teaching excellence, social mobility and student choice' published May 2015.
} 
Later the 'Success as a Knowledge Economy: Teaching Excellence, Social Mobility and Students Choice' paper in 2016 (White Paper) confirmed the green paper and stated that the purpose of TEF is two-fold, on the one hand, 'to provide clear information to students about where the best provision can be found'; ; and on the other hand, 'to drive up the standard of teaching in all universities. ${ }^{4}$ An idea is clear, TEF will bring changes in the UK's Higher Education horizon, and to how HE is being evaluated. To start with we know that TEF will offer three ratings: gold, silver and bronze. The metrics of TEF will include an institutional report submitted by the university and 'common sector' indicators. The report submitted by the university can featured whatever the universities want to present, from learning analytics to employer engagement, or staff pedagogical qualifications for example through the Higher Education Academy $;^{5}$ they will probably also include some of their enterprise activities on this institutional report. On the other hand, TEF looks at the common sector indicators which are a compendium of data: firstly, students' employment and earnings data out of the Destination of Leavers Survey from HE (DLHEA); secondly, students' retention and continuation this information comes out of the HE Statistics Agency (HESA), and lastly, students satisfaction information from the National Student Survey (NSS). In principle, all this data is set to measure teaching quality, so TEF will help inform students, employers and, of course, the competitive market. The reality is that there are fears by university teachers that TEF is used by policy makers and that evidence-gathering of quality is just part of 'New Public Management' ${ }^{6}$ The underlined position with which universities and their teachers have to contend, is one in which students and the employer deserve better for their money; ${ }^{7}$ As we will try to show in the next sections.

\subsection{TEF and the Students as Consumers.}

Starting in 2012/13 when students' fees in the UK became $£ 9,000$, there was this feeling that the excellent HE in the UK, was becoming 'marketised and consumer-led' ${ }^{8}$ Later in 2015, the Government t $^{9}$ together with Which? (the largest independent consumer body in the UK) and its report 'A Degree of Value' stated that teaching in HE was poor and students dissatisfied. ${ }^{10}$ In fact, this was not the general feeling in the HE sector based on the National Student Survey that was presenting good levels of satisfaction by

\footnotetext{
${ }^{3}$ DEPARTMENT FOR BUSINESS INNOVATION AND SKILLS (White Paper 2016) 'Success as a Knowledge Economy: Teaching Excellence, Social Mobility and Students Choice' Published 16 May 2016

${ }^{4}$ Ibid

HIGHER EDUCATION ACADEMY (Qualifications) in

https://www.heacademy.ac.uk/individuals/fellowship/fellow accessed 22/12/2017

${ }^{6}$ WOOD M and SU F (2017) "What makes an excellent lecturer? Academics' perspectives on the discourse of 'teaching excellence' in higher education" in Teaching in Higher Education Vol 22, No 4, 2017 p. 460

7 ROBINSON W and HILLI A (2016) "The English 'Teaching Excellence Framework' and Professionalising Teaching and Learning in Research-Intensive Universities: and Exploration of Opportunities, Challenges, Rewards and Values from a Recent Empirical Study' in Foro de Education, Vol 14 No 21, 2016, p.153

${ }^{8}$ Ibid

${ }^{9}$ MORGAN J, (2015) 'Jo Johnson Under Fire for Calling some University Teaching Lamentable' times Higher education (8 December 2015) https:/www.timeshighereducation.com/news/jo-johnson-underfire-calling-some-university-teaching-lamentable accessed 24/12/2017

${ }^{10}$ WHICH? (2014) 'A Degree of Value: value for money from the student experience' (November 2014)
} 
students. Regardless, Which? advised on a new regulatory system for HE more akin with consumer protection regulation. ${ }^{11}$ Higher Education started to appear as 'a business and revenue generator'. ${ }^{12}$ Pushing these changes we have the Consumer Rights Act (CRA) $2015 .^{13}$ It is clear that students are to be treated more as 'consumers' of H.E and that fact changes their behaviour. ${ }^{14}$ Since the fees came up to $£ 9,000$ we are getting the 'I'm paying you' mindset of our students. Students are consumers that look at what they get for their money. ${ }^{15}$ It is not only the influence of the CRA at play, but also the Higher Education and Research Act (HERA) 2017. ${ }^{16}$ Recently, the Lords wanted to stop TEF being used to set (increase) university fees. In the end the Government rejected the Lords proposition, as a result of this 'stand-off', the introduction of a link between TEF and differentiating tuition fees is not ended; but only delayed till 2020 ('until an independent review of the exercise's metric is complete'). ${ }^{17}$ Maybe they tried to fight the idea of some that reforms in HE are not about advancing teaching or learning, but about getting higher fees. ${ }^{18}$ From the point of view of students as consumers, and this affects also their employment, if universities are set to give students all that they perceived they paid for, we are making them dependent to all those outcomes the University owes them; are these 'consumer rights-inflated' students what society needs ${ }^{19}$

University teachers are really stressed about results such as NSS scores, ${ }^{20}$ and get their managers on their case quite often. On top of that, the extra help this generates towards students in order to do well on their courses and get good NSS results is not doing them any favours; we are not challenging students enough. ${ }^{21}$ Furthermore, this has developed on the phenomenon of 'grade inflation' (a great number of students are achieving very high marks on their degrees). ${ }^{22}$ Pressures through measurement of performance and the

\footnotetext{
${ }^{11}$ NEARY M (2016) "Teaching Excellence Framework: a critical response and an alternative future" in Journal of Contemporary European Research Vol 12 No 3, 2016, p. 690

${ }^{12}$ HUBBLE S, FOSTER, D Foster and BOLTON P (2016) 'Higher education and Research Bill' Briefing Paper No 7608 published 30 June 2016 (p. 6)

13 CONSUMER RIGHTS ACT 2015.

14 BUNCE L, BAIRD A and JONES S E (2017) "The Student-as-a-consumer Approach in higher education and Its Effect on Academic Performance" in Studies in Higher Education. Vol 42 No 11, 2017, p. 1958-1978

${ }^{15}$ FRANKHAM J (2017) "Employability and higher education: the follies of the 'Productivity Challenge' in the Teaching Excellence Framework in Journal of Education Policy, Vol 32 No 5, 2017 p.635

${ }^{16}$ HIGHER EDUCATION AND RESEARCH ACT 2017

${ }^{17}$ MORGAN J (2017) 'Higher education and Research Bill passed by UK Parliament ' (27 April 2017 in the Times Higher Education. https://www.timeshighereducation.com/news/higher-education-andresearch-bill-passed-uk-parliament\#survey-answer accessed 25/12/2017

18 HEANEY C and MACKENZIE H (2017) "The Teaching Excellence Framework: Perpetual Pedagogical control in Postwelfare Capitalism" in Compass: Journal of Learning and Teaching Vol 10 No 2, 2017, p. 2r

${ }^{19}$ FRANKHAM 'Employability and HE' op cit 634

${ }^{20}$ SABRI D (2013) "Student evaluations of Teaching as 'Fact-Totems': The Case of the UK National Student Survey' in Sociological Research Online Vol18 No 4 (published 30 Nov 2013) http://www.socresonline.org.uk/18/4/15.html

${ }^{21}$ WOODALL T, HILLER A and RESNICK (2014) "Making Sense of Higher Education: Students as Consumers and the Value of the University Experience" in Studies in Higher education Vol 39 No1, 2014, p. 48-67

${ }^{22}$ BACHAN R (2017), "Grade Inflation in UK Higher Education" in Studies in Higher Education, Vol 42 , No 8,2017 , p. $1580-1600$
} 
'marketisation of the $\mathrm{HE}$ ' is not helping society, 'performance grades' fails what employer needs, which is students that are learners, problem-solvers and independent thinkers, and not just students with high marks. ${ }^{23}$ The green paper highlights the problem of 'grade inflation'. (green paper p. 12). In fact, the system is creating students that are perhaps too dependent and not able to think for themselves, that is actually what employers are complaining about in the first place; ${ }^{24}$ and TEF is worried about employability to.

\subsection{TEF and Employability.}

Indeed, there is another element academics are facing with TEF: it is 'Employability'; it is one of the words at the centre of TEF. ${ }^{25}$ There is a lot of involvement of Higher Education on employability of the students. ${ }^{26}$ In reality, the HE is a sector in which employability is gaining importance by the day; students need much more than just knowledge. ${ }^{27}$ The green and white paper in TEF, are clear to show that employability, or more to the point, 'what employers want ${ }^{\text {'2 }}$ should be a driving force for Universities. The green paper started the idea that universities need to help 'increase productivity' (green paper p 10), the white paper was even clearer, the agenda was set, H E was to help with the skills gap affecting the productivity of the nation (white paper p.10). ${ }^{29}$ While it is not exactly clear what employability means; the burden for academics seems to be set: we need to produce 'work ready' students. Employability of students actually affect universities league places and their recruitment. ${ }^{30}$ Unfortunately, despite this move towards employability; in reality, data shows that this pressure is not transforming the labour market or benefiting the prospect of young people. ${ }^{31}$ Still, some university teachers are actively looking at embedding employability skills on their modules, ${ }^{32}$ but what is happening with those academics 'proper pedagogical' teaching under TEF?

\footnotetext{
${ }^{23}$ LYNCH R and HENNESSY J (2017) "Learning to earn? The role of performance grades in higher education" in Studies in Higher Education Vol 42 No 9. 2017, p. 1750-1763

${ }^{24}$ THOLEN G et al. (2016) "Higher Education, Graduate Skills and the Skills of Graduates: The Case of Graduates as Residential Sales Estate Agents" in British Educational Research Journal Vol 42 No 3, 2016, p. 508

${ }^{25}$ FRANKHAM 'Employability and HE' op cit 628

${ }^{26}$ BADLEY G (2016) "The Pragmatic University: A Feasible Utopia?" in Studies in Higher Education Vol 41 No 4, 2016, p. 633

${ }^{27}$ JACKSON D (2015) "Employability skill development in work-integrated learning: Barriers and best practice" in Studies in Higher Education Vol 40 No 2, 2015, 354

${ }^{28}$ COLLINI S (2016) "Who are the Sponger Now?" in London Reviews of Books, Vol 38 No 2, 2016, p. 33

${ }^{29}$ FRANKHAM 'Employability and HE' op cit 629

${ }^{30}$ TYMON A (2013) "The Student Perspective on Employability" in Studies in Higher Education, Vol 38 No 6, 2013, p. 843

31 'Students, particularly those from a white working-class disadvantaged background, are less likely to go to University than they were in the 1960s' as in SMITH G and SMITH T (2014) "Tackling Educational disadvantage by Area: continuity and Change to Urban Areas in England 1968-2014" in Oxford Review of Education Vol 40 No 6, 2014, p. 718

32 RIGG D (2013) "Embedding employability in Assessment: Searching for the balance between academic learning and skills development in law: A case study" in The Law Teacher Vol 47 No 3, 2013, 412; FRANKHAM 'Employability and HE' op cit 631
} 


\subsection{TEF and Teaching.}

Some, quite pessimistically, think that measuring through TEF will actually produce an opposing effect and will probably slow down the improvement of 'teaching' in universities. ${ }^{33}$ The reasons behind this are various. On the one hand, some commentators declare that TEF is looking at 'teaching excellence' in HE through very narrow lenses, neglecting to measure the understanding and developing of quality in teaching. ${ }^{34}$ They argue that TEF should include measurements of what learners understand by excellence in teaching and what teachers understand by excellence in teaching. University teachers will locate 'teaching excellence' not just on the data TEF uses at this moment but 'within the pedagogical relationship between teacher and learner' ${ }^{35}$ Wood and Su remark that in order to make TEF a more meaningful exercise it needs to recognise:

'a more nuanced inclusive interpretation of teaching excellence which recognise the conjoined nature of teaching and research in higher education, and also rebalance the focus on outcome-related measure with understanding the purposes and development of the processes of learning. ${ }^{36}$

On the other hand, some go as far as stating that TEF will stop diversity in HE and in learning in general. ${ }^{37}$ In fact, TEF talks about diversity in the sense of 'Widening Participation' groups, meaning to include 'national' groups that are underrepresented, like: low income, students with disabilities, or adults learners that come back to education; but no references to international students. ${ }^{38}$ Hayes insists that TEF should include metrics that will measure if international students are treated equally to national ones and how academics promote 'intercultural relationships' ${ }^{39}$ This sounds better that the notion of looking at international students just as an economic benefit as they pay more fees than home students. ${ }^{40}$ It is clear that teaching excellence is not complete by ignoring international students' perspectives; this will be, certainly, a missed opportunity for $\mathrm{TEF}^{41}$ In sum, the complaints about TEF are built around what the metrics are missing:

'Somewhat missing from the current English debate on the TEF is a discussion about different approaches to pedagogy, curriculum and different teaching and

\footnotetext{
${ }^{33}$ WOOD and SU 'What makes an excellent lecturer' op cit 461

${ }^{34}$ Ibid 453

${ }^{35}$ Ibid 462

${ }^{36}$ Ibid 462-3

${ }^{37}$ BOXALL (2016) 'Higher Education White Paper: The Big Changes' Higher Education Network. The Guardian, 16 May 2016. https://www.theguardian.com/higher-education-network/2016/may/16/highereducation-white-paper-the-big-changes accessed 25/12/2017

${ }^{38}$ HAYES A (2017) “The Teaching Excellence Framework in the United Kingdom: An Opportunity to Include International Students as 'Equals'?” in Journal of Studies in International Education Vol 21 No 5,2017 , p. 485

${ }^{39}$ Ibid 491

${ }^{40}$ BOLSMANN C and MILLER D R (2008) "International student recruitment to universities in England: Discourse, rationales and globalisation" in Globalisation, Societies and Education Vol 6, 2008, p. 77.

${ }^{41}$ HAYES “The TEF the UK' op cit 484
} 
learning styles in HE and the impact that these might have on student learning and outcomes ${ }^{42}$

In any case, to the Government's green and white paper we have to add the creation of the Office for Students, that will the now the 'Single Market Regulator in Higher Education, ${ }^{43}$ which will be established to protect interests of students, employers and tax payers ${ }^{44}$ Unsurprisingly, there is no mention of University teachers, whose voice is being muted.

\subsection{TEF and the University Teachers.}

'...we are in economic trouble because our universities are not producing the 'work-ready' employees we need; they must be required to do better in this regard, doing better will be judged by metrics developed from outside the academy. Failings will be laid at the door of academics. ${ }^{45}$

In fact, University teachers will be under the scrutiny of the CRA if they do not deliver courses to a minimum standard and are under the shadow of consumer law remedies. ${ }^{46}$

However, we have to announce one advantage of this whole TEF process for university teaches; particularly for teaching-dominant staff; the advantage is the foreseeable rise of the status of teaching staff over research-dominant staff. ${ }^{47}$ This may help to balance the existent supremacy of research staff over teaching staff. ${ }^{48}$ For some time staff have felt that career prospects are limited to research intensive staff more than teaching staff, which will have more hours allocated to teaching and less to research. ${ }^{49}$ Universities minister Jo Johnson said:

'The Teaching Excellence Framework is refocusing the sector's attention on teaching - putting in place incentives that will raise standards across the sector and giving teaching the same status as research. ${ }^{50}$

42 ROBINSON W and HILLI A (2016) “The English 'Teaching Excellence Framework' and Professionalising Teaching and Learning in Research-Intensive Universities: and Exploration of Opportunities, Challenges, Rewards and Values from a Recent Empirical Study' in Foro de Education, Vol 14 No 21, 2016, p. 163

43 DEPARTMENT FOR EDUCATION, "Office for Students: regulatory framework for higher education” (Published 19 October 2017). A recent consultation (from 19 October 2017-22 December 2017) has been launched.

${ }^{44}$ FRANKHAM 'Employability and HE' op cit 636

${ }^{45}$ Ibid 637 .

${ }^{46}$ NEARY 'TEF a critical response' op. cit 690-1

${ }^{47}$ WOOD and SU 'What makes an excellent lecturer' op cit. 460

48 BLACKMORE P (2016) "Why Research Trumps Teaching and What can be Done About It" in Tackling Wicked Issues: Prestige and Employment in the Teaching Excellence Framework, ed, $\mathrm{P}$ Blackmore, R. Blackwell, and M Edmondson, 2016, Oxford. Occasional Paper 13, p 9

${ }^{49}$ ROBINSON and HILLI 'TEF and Professionalising Teaching' op.cit. 159

${ }^{50}$ PELLS R (2017) 'Elite UK universities found to be second-rate in new Government ratings' 21 June 2017, More than half of Russell Group institutions - traditionally considered to the best in the country did not score top marks. http://www.independent.co.uk/news/education/education-news/top-ukuniversity-rankings-gold-silver-bronze-oxford-cambridge-tef-teaching-excellence-framework-newa7801681.html accessed 29/12/2017 
In conclusion, the metrics of TEF as seen above, are criticised as not good at measuring quality of teaching or more importantly learning. ${ }^{51}$ More to the point of this section, they are 'far-removed' from those academics that teach in universities, ${ }^{52}$ which see 'teaching excellence' as the ability to enable students to learn. On another note, there is no doubt that TEF metrics are adding another pressure to UK universities, apart from research they have to start introducing a 'culture' in which quality teaching and learning is recompensed ${ }^{53}$ but this pressure will percolate down to university teachers.

On a practical level, the first TEF results were published a few months ago: it comprises $134 \mathrm{HE}$ institutions and three alternative providers; of which 45 received gold, 67 silver and 25 received bronze. ${ }^{54}$ The problem with these results was that for example a 'worldrenowned' university such as the London School of Economics was awarded bronze. Many went back to blame the metrics that look more at 'effects' of teaching than 'quality' of teaching. ${ }^{55}$ Another criticism is than TEF is not specifying the quality of individual degree programmes; this means that a university with a bronze award can offer excellent degree programmes and; on the other hand, there can be not that good degrees being delivered on universities which were awarded a gold. ${ }^{56}$ Lately, there has being talk about adding another metric such as contact hours with students, still does not indicate quality in teaching for many; the challenge is there is not metric about the 'expertise' of those who teach $;{ }^{57}$ even though universities are pressuring their teachers to get pedagogical qualifications (i.e. HEA qualifications) ${ }^{58}$ In sum, the big dilemma with TEF is that if it is based on:

'(...) measures that are unrelated to the quality of teaching, then it will end up measuring institutional game-playing rather than excellent teaching, ${ }^{59}$

To this worrying climate in HE in general we have to add another perturbing element to legal education in particular, which is the brand new proposed Solicitors Qualifying Exam: the SQE.

\section{The Solicitors Qualifying Exam.}

As of now, the typical way to qualify in England and I Wales as a solicitor is to pursue a qualifying law degree (QLD) or a graduate diploma in law (GDL).$^{60}$ This degree is then

\footnotetext{
${ }^{51}$ HOLYROYD J and SAUL J (2016), 'Will the Teaching Excellence Framework Be Sexist' the Guardian (4 April 2016) https://www.theguardian.com/higher-education-network/2016/apr/04/willthe-teaching-excellence-framework-be-sexist accessed 25/12/2017

${ }^{52}$ ROBINSON and HILLI 'TEF and Professionalising Teaching' op.cit. 155

${ }^{53}$ Ibid 156

54 'Teaching excellence framework (TEF) results 2017 (june 22, 2017) source iStock https://www.timeshighereducation.com/news/teaching-excellence-frinamework-tef-results-2017 accessed $23 / 12 / 2017$

55 ibid

${ }^{56}$ Ibid

${ }^{57}$ Ibid

${ }^{58}$ HIGHER EDUCATION ACADEMY in https://www.heacademy.ac.uk/individuals/fellowship/fellow accessed 22/12/2017

${ }^{59} \mathrm{TEF}$ the results source iStock
} 
followed up by a legal practice course (LPC), which comes before a training contract. The training contract usually consist on a two-year period spent working at a law firm, to put into practice all the knowledge and skills acquired through the degree and the LPC. Even though the SRA does not deny that the current framework produces 'highly competent' practitioners; it has decided to dismantle the existent system by a centralised SQE. ${ }^{61}$ To start with, the SQE will only apply to Solicitors, not to Barristers. The Bar Standard Board (BSB) will still require that future Barristers hold a QLD, take a Bar Vocational Course and pupillage (one-year period training) in a barrister's chambers. More importantly according to Bradney:

'...the Bar Standards Board at present are minded to do the reverse of what the SRA is doing, keeping the requirement to have a degree for qualification as a barrister but increasing the class of degree that will be necessary from lower second to upper second. With it now being possible for clients to directly approach a barrister in the future the Bar may be able to argue that barristers are more highly qualified then solicitors. ${ }^{62}$

In any case according to Rowland (SRA Chair) the new centralised exam will help the all familiar employers and consumers:

'Our proposals are all about setting and assuring high, consistent, professional standards for the future...the new SQE will serve the public, consumers, employers and the profession well.'

As we will see many disagree with those assertions; and it is safe to declare that the SQE proposal has generated a bitter backlash, not only from the employers and profession, but from universities. The latter have been positioned on a 'crossroads'; according to Jackson and McConnell there are a few plausible responses by universities' law schools: firstly, 'no change' particularly for elite law schools that will still retain their reputation and power of appeal to students; secondly, 'minimal change' for those high ranking institutions that may run some SQE courses commissioned to private companies; thirdly, 'professional stream' that will mean some law schools creating modules with professional elements linked to some aspects of the degree and embedding them in the curriculum; and lastly, 'full integration' this would mean for some law schools having to market programmes for those that want to practice law, it would mean to integrate many of the SQE requirements into the degree offered ${ }^{63}$ In any case, the SQE has rattled universities and their management, it may in some cases affect the curriculum and the ones delivering it, the law teachers. But before we look more

\footnotetext{
${ }^{60}$ A GDL is a one-year postgraduate conversion course for those that already have a non-law undergraduate degree and want to enter the legal career.

${ }^{61}$ HARDEE M (2016) 'Central Exam idea does not add up' in the Law Society Gazette, (29/02/2016) https://www.lawgazette.co.uk/features/central-exam-idea-does-not-add-up/5053909.article accessed 28/12/2017

${ }^{62}$ BRADNEY A (2016)“'Dumbing down the Law: The SRA proposals for Legal Training' in Politeia http://www.politeia.co.uk/wp-content/Politeia\%20Documents/2016/Feb\%20-

\%20Dumbing\%20down\%20the\%20Law/'Dumbing\%20Down\%20the\%20Law'\%20Feb\%202016.pdf accessed 29/12/2017

63 JACKSON N and McCONNELL (2017) "Academic Lawyers and the new Solicitors Qualifying Examination: What stands in the way of consensus ad idem? (unpublished - in file with authors) p.2 1
} 
closely into the effects of the SQE on the profession and universities we need to look at the reasons behind the SQE.

\subsection{SQE and its Reasons.}

In 2011 there was a review conducted by the SRA, the BSB and Ilex Professional Standards (IPS) into the trainings and education obligations for legal services in England and Wales. The review was published in 2013 under the name of the Legal Education and Training Review (LETR) ${ }^{64}$ The SRA based on the topics discussed on LETR came up with the programme 'Training for Tomorrow' and began a consultation on the standard of competence that should be expected from solicitors and then issued a consultation on a Solicitors Qualifying Exam 'for all new solicitors' ${ }^{65}$ Since then there has been up to five consultations, from 'Training for tomorrow: Assessing Competence $^{66}$ ' to 'A new route to qualification' ${ }^{97}$ and 'Consultation Response and Our Decision on Next Steps.' ${ }^{68}$ It is clear that as a Regulator the SRA is obliged to consult; but not to listen to stakeholders and make changes. Hence, the consultations are just, in reality, an exercise on presenting what has been decided. Regardless, the SRA highlighted some reasons to bring on the SQE, like: problems with social mobility/diversity and inconsistencies in the actual system. Regarding the first reason, the SRA complained about the price of some LPCs (up to $£ 15,000^{69}$ in some cases) and how this would affect social mobility in the profession. Social mobility in the legal context is obviously a problem, and recruitment appears bias towards Oxbridge/pre1992 university students. ${ }^{70}$ Furthermore, according to the SRA training contracts are averse to diversity in the legal profession. Following SRA data only $24 \%$ of trainee solicitors come from a Black, Asian and Minority Ethnic (BAME) background, when $37 \%$ of them are law students and 32\% completed the LPC. Maybe by eliminating the LPC and separating training for assessment becoming a solicitor would be affordable and help diversity. ${ }^{71}$

The other reason presented by the SRA is stated by Brannan (SRA Director of education and training) on the following statement:

\footnotetext{
64،LETR: Setting Standards: the Future of Legal services education and Training Regulation in England and Wales' published in June 2013

${ }^{65}$ FRY E and WAKEFORD (2017) "Can we really have confidence in a centralised Solicitors Qualifying Exam? The example of the Qualified Lawyers Transfer Scheme" in The Law Teacher Vol 51 No 1, 2017, p. 98

66 SOLICITORS REGULATION AUTHORITY 'Training for tomorrow: Assessing competence', Consultation on a proposal to introduce the Solicitors Qualifying Examination: Consultation Response (Published October 2016)

${ }^{67}$ SOLICITORS REGULATION AUTHORITY 'A new route to qualification: the Solicitors Qualifying Examination' (25 April 2017)

${ }^{68}$ SOLICITORS REGULATION AUTHORITY 'Consultation Response and Our Decision on Next Steps' (April 2017)

${ }^{69}$ LPCS do not qualify for students' loans.

${ }^{70}$ FERGUSON L (2017) "Complicating the 'holy grail', simplifying the search: a critique of the conventional problematisation of social immobility in elite legal education and the profession" in The Law Teacher Vol 41 No 4, 2017, 378

${ }^{71}$ SRA Diversity Page http://www.sra.org.uk/risk/outlook/priority-risks/diversity.page accessed $29 / 12 / 2017$
} 
'...in 2013-2014 there were 104 providers of the QLD, 33 GDL providers, 26 providers of the LPC and 4,611 training contract providers. It would be surprising if standard were consistent across these members of organisations, ${ }^{72}$

As a result of the SRA's perception of inconsistencies in degrees and in training for solicitors pushed the idea for the need of a central assessment that would mitigate the inconsistencies; the SRA proposed doing this by copying the New York Bar exam. In fact, we should point out that there are differences between the UK and the US systems $;{ }^{73}$ for example, in North American universities legal education is not delivered to undergraduates, but graduates (the students already hold a degree), delivering legal education only to postgraduate level. ${ }^{74}$ Also, in the US there is no legal training as in the UK where at the minute there is the LPC followed by a training contract. In the US law graduates sit bar exams to enter the legal profession in various states; these graduates can practice once they pass the exam. ${ }^{75}$ Commentators like Fry and Wakeford have had a look at how this centralised SQE could work in the UK, based on a study of the existing Qualified Lawyers Transfer Scheme (QLTS) ${ }^{76}$, which is a 'comprehensive centralised assessment' for lawyers from other jurisdiction and barristers ${ }^{77}$ to qualify as solicitors of England and Wales. ${ }^{78}$ Both authors are hopeful that (based on their study) the SQE can work if some 'prerequisites' are meet: such as 'robust design, appropriate development of questions and training of assessors and insightful psychometric support' ${ }^{79}$ More details on the practicalities of the actual SQE, which will be introduced from 'late $2020^{, 80}$ will be discussed in the next section.

\subsection{SQE and its Practicalities.}

As announced above, the new proposal set in the SRA is for new solicitors to pass a centralised exam, the SQE. The exam present two parts: the first part, would test the ability to 'use and apply legal knowledge'; the second part, would test 'legal skills'. The SQE is mapped to Miller's Pyramid (Figure 1) according to the SRA. Stage 1 of the SQE is aimed at assessing the two lower levels of the pyramid; Stage 2 of the SQE will assess the higher two levels.

\footnotetext{
${ }^{72}$ J Brannan, SRA director of education and training; 'Speech to the Junior Lawyers Division Executive Committee’ (19 April 2015) https://www.sra.org.uk/sra/news/events/conference-2015-04-19-juniorlawyers-division.page accessed 30/12/2017

${ }^{73}$ DONNELLY C (2012) "Convergences and Divergences in educating Transnational Lawyers in The International Lawyer Vol 46, 2012, p. 627

${ }^{74}$ Ibid $627-8$

${ }^{75}$ Ibid 630

${ }^{76}$ Introduced by the SRA ON 2010

${ }^{77}$ From England and Wales

${ }^{78}$ Was introduced in 2010 by the SRA replacing the Qualified Lawyers Transfer Test (QLTT), introduced in 1990. The QLTS was inspired on assessment methodologies used in other jurisdictions such as medicine, in FRY E. CREWE J and WAKEFORD (2013) 'Using multiple choice questions to examine the content of the qualifying law degree accurately and reliably: the experience of the Qualified Lawyers Transfer Scheme, (2013) The Law Teacher Vol 47, No 2, 234

${ }^{79}$ FRY E and WAKEFORD (2017) "Can we really have confidence in a centralised Solicitors Qualifying Exam? The example of the Qualified Lawyers Transfer Scheme” in The Law Teacher Vol 51 No 1, 2017, p. 99

${ }^{80}$ SRA website
} 


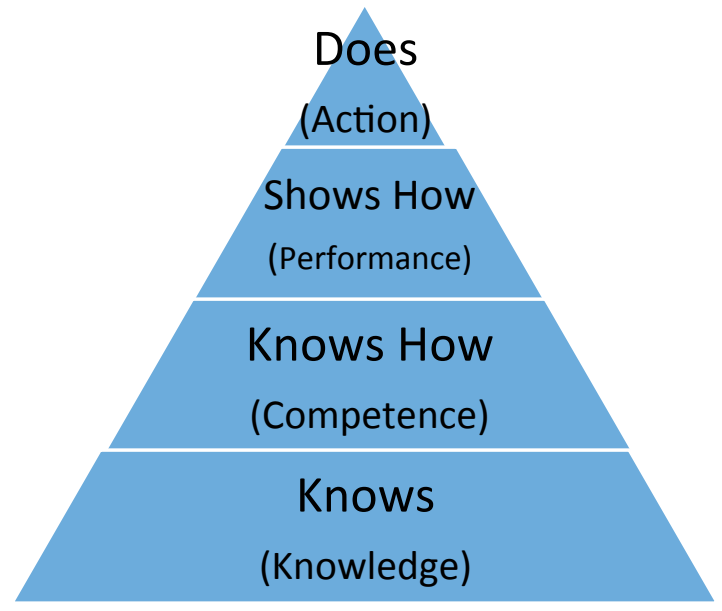

Figure 1: Miller's Pyramid ${ }^{81}$

The Overview of the SQE is presented (in Figure 2 ) $^{82}$ below. The first stage of the SQE 'functioning knowledge assessments' would be tested using computed-based objective testing. The questions will be single best answers, extended matching questions and multiple-choice questions. All of these assessments will include 'unflagged ethical question' ${ }^{83}$ In principle Universities are worried about this Stage 1, as in theory Stage 2 should come after some work experience. However, some have already flagged out the fact that a law degree is not essential anymore in order to become a solicitor:

'...the law degree is not an essential pre-requisite for safe practice as a solicitor... To think that a computer-based, multiple-choice question examination is the equivalent of three years of study and intellectual development on a law degree... is quite simply bonkers. ${ }^{84}$

Also, while the SRA expects candidates to take stage one of the examination before getting any work-based experience; the SRA introduces another change with the SQE. The new system will recognise experience outside the typical training contract: hence, it can be accepted as 'work-based learning' if the candidate had worked in a student law clinic, ${ }^{85}$ or work experience as an apprentice or paralegal ${ }^{86}$, and similarly placement as part of a sandwich degree.$^{87}$ Candidates can actually sit SQE stage 2 without having

\footnotetext{
${ }^{81}$ MILLER G E (1990) "The Assessment of Clinical Skills/Competence/Performance" in Academic Medicine Vol 65 No 9, 1990. P 63-67.

82 SRA, Overview of the SQE in Annex 1: Assessment Specification p.6 https://www.sra.org.uk/sra/consultations/solicitors-qualifying-examination.page\#download

${ }^{83}$ Ibid

${ }^{84}$ HARDEE ‘Central Exam' op. cit.

${ }^{85}$ Law school programmes that provide hands-on-legal experience to students and normally provides free legal services to clients usually directed by members of staff that are practitioners.

${ }^{86}$ They provide support to solicitors and barristers.

${ }^{87}$ Is a four-year undergraduate course in which students undertake one-year placement on a firm; usually after the second year at university.
} 
completed the work-based learning (18 to 24 months), but it will be required completed before admission as a solicitor. ${ }^{88}$

Another big change we cannot forget is that the LPC is not a requirement any more. The SRA through the SQE has shown that 'assessment will now be separate from and independent of training. ${ }^{89}$ There may be replacement courses to the LPC or some solicitors apprenticeship that will include what is required to pass the SQE. The reality is that some city (London) firms are used to hiring certain providers of LPC, which offer courses tailored to those specialist firms. Undoubtedly, it is going to be more difficult for those specialist law firms to make sure their trainees have 'all' the experience required now by the SRA in the new SQE. Particularly, if many of the subjects' content required in the SQE are not relevant to their specific business. ${ }^{90}$

\section{Figure 2}

\begin{tabular}{|c|c|}
\hline \multicolumn{2}{|c|}{ Overview of the SQE } \\
\hline Stage 1 & Stage 2 \\
\hline $\begin{array}{l}6 \text { x Functioning Legal Knowledge } \\
\text { Assessments: } \\
\\
\\
\text { Principles of Professional } \\
\text { Conduct, Public and } \\
\text { Administrative Law, and the Legal } \\
\text { Systems of England and Wales } \\
\text { Dispute Resolution in Contract or } \\
\text { Tort } \\
\text { Property Law and Practice } \\
\text { Commercial and Corporate Law } \\
\text { and Practice } \\
\text { Wills and the Administration of } \\
\text { Estates and Trusts } \\
\text { Criminal Law and Practice. }\end{array}$ & 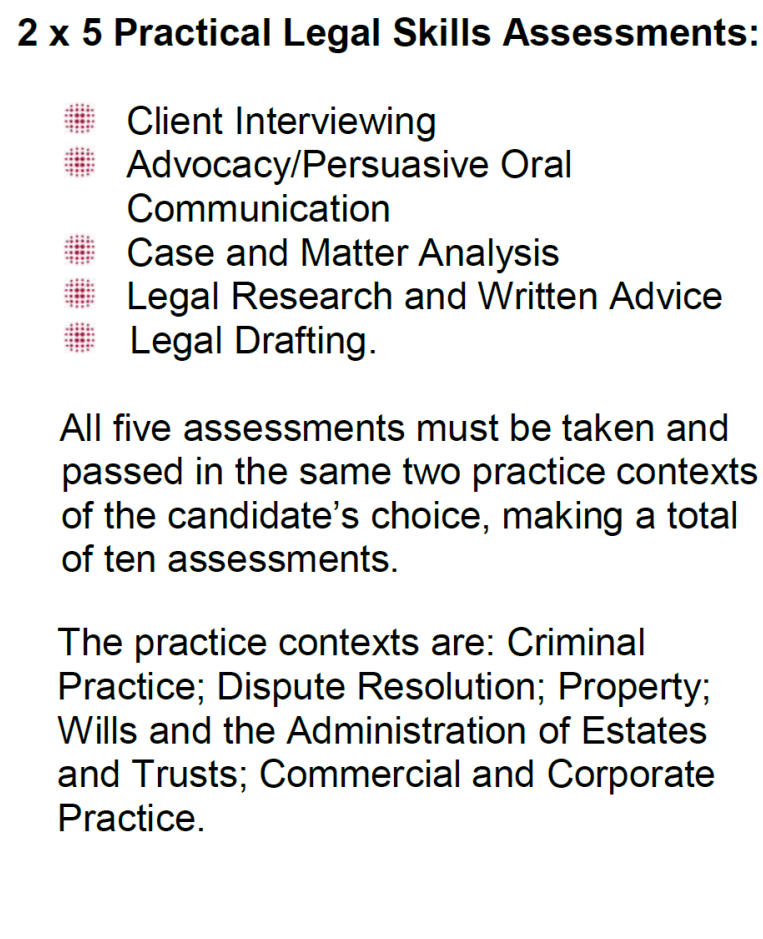 \\
\hline
\end{tabular}

In conclusion, anyone wanting to be a solicitor after 2020 will have to:

- Have a degree or equivalent qualification (i.e. apprenticeship)

- Pass the SQE

\footnotetext{
${ }^{88}$ SOLICITORS REGULATION AUTHORITY web page

${ }^{89}$ Ibid

${ }^{90}$ HARRIS M Harris (2015) 'The legal education system may soon be overhauled - here's how' (7 December 2015) the Guardian https://www.theguardian.com/law/2015/dec/07/the-legal-educationsystem-may-soon-be-overhauled-heres-how accessed 23/12/2017
} 
- Complete the qualifying legal work experience

- Surpass the SRA's character and suitability test. ${ }^{91}$

These requirements will be the same for overseas lawyers; thus, we can wave farewell to the QLTS. ${ }^{92}$ At the moment any exemption offered to EU nationals that work in the British legal profession will depend on any agreement reached on access to the single market. ${ }^{93}$

Unquestionably, the SQE has opened an alternative way to be a solicitor that does not necessitate to study full-time at a University and completing an LPC, with all the money that fees for both entail. There may be many prospective solicitors attracted to this new path; however, as we will see in the next section, this new path has had a hostile reception not just by parts of the profession but by universities and law teachers.

\subsection{SQE and its Immediate Reactions.}

Looking at the immediate response, the SQE has got a challenging road ahead. It is clear that the SQE will have more impact on the profession than on Universities' law schools, as not all law graduates become solicitors. Moreover, it is expected that in actual fact 'the vast majority of solicitors will have degrees. ${ }^{94}$ Besides, law degrees are seen as one of 'the useful degrees to have'. ${ }^{95}$ The problem is that if the SRA keeps pushing the idea that solicitors do not need degrees, it may reduce confidence on the profession of being a solicitor. ${ }^{96}$ Those providing training for firms have warned that:

'These proposals if implemented will seriously damage this country's legal profession's international standing. All our major competitor jurisdictions require their lawyers to be educated to at least Masters' level. Assessing competence to practice at a lower level threatens the standing, quality and reputation of the solicitors' profession. Given that most professions including nursing, teaching...the police are now graduate-entry professions, the SRA's proposals lack credibly and will undermine public confidence in the legal profession, 97

The international standing of legal education is complicated by adding the Brexit 'saga', as UK universities still want to collaborate with those not leaving the EU; ${ }^{98}$ it will take

\footnotetext{
91 LAW CAREERS NET 'The Solicitors Qualifying Examination: everything we know so far' LawCareers.Net on 13/06/2017. https://www.lawcareers.net/Information/Features/13062017-TheSolicitors-Qualifying-Examination-what-we-know-so-far accessed 28/12/2017

${ }^{92}$ QLTS Candidates that have completed successfully QLTS 1 could choose to do QLTS 2 (subject to availability) or SQE stage 2. For postgraduate conversion after September 2020.

${ }^{93}$ SOLICITORS REGULATION AUTHORITY web page

${ }^{94}$ BRADNEY, 'Dumb the Law ' op.cit 25

95 FURNHAM A and PERTRIDES K (2010), 'The best university degrees to get a job' in Higher Education Review Vol 42, 2010, 54

${ }^{96}$ BRADNEY, 'Dumb the Law' op.cit 22

${ }^{97}$ Professor Crisp, Dean of BPP University’s Law School, which provides training for over 50 leading law firms, in BRADNEY, 'Dumb the Law' op.cit 18

98 The European Commission has warned on its research and innovation portal that if the UL withdraws without agreement British researchers will lose their grants under Horizon 2020.
} 
at least a decade for UK universities to settle agreements with EU countries individually. ${ }^{99}$ Moreover, UK universities are worried about their European staff being grabbed by other EU members. ${ }^{100}$ But this will be clearly subject for another paper.

In a more practical level, to the SRA rationale or purpose of allowing more people to become solicitors, by facilitating more social mobility and diversity, Hardee brings an obvious fact: there are a limited number of training places. The SRA needs to accept that there are more law graduates than training contracts. "not everyone who wants, gets'. ${ }^{101}$

What the SRA should be asking is whether law graduates have made an informed decision to study law, knowing the limited opportunities for training places available, and whether the numbers of law graduates are inflated by students who are not going to meet the required standards but who have been enticed onto law degrees by universities whose funding pressures require them to enroll as many students as possible on their law degree programs? ${ }^{102}$

The SRA accepts there is clear opposition from academics institutions. ${ }^{103}$ Bradney states that many associations representing those in university law schools: The Association of Law Teachers, the Committee of Heads of University Law Schools, the Society of Legal Scholars and the Socio-Legal Studies Association, were all clear that 'the SRA's suggestions were fundamentally flawed. ${ }^{104}$ For example, the Society of Legal Scholars commented that:

'...neither the Legal Education and Training Review nor subsequent research has shown that there is a substantial body of evidence that shows the need for radical changes to existing arrangements, 105

More particularly, Hall denounces discrepancy in the data offered from one of the Consultations of the SRA. ${ }^{106}$ In sum, some universities and law teachers are denouncing the danger of 'over-regulation based on inadequate evidence.' 107 Furthermore, academics like Moorhead criticize also the type of qualifying law degree the SRA may sponsor:

\footnotetext{
${ }^{99}$ WILSON L (2017) 'A bad-tempered Brexit is a risky mover for universities' L. Wilson (The Guardian) 11/11/2017 https://www.theguardian.com/higher-education-network/2017/oct/11/brexit-cool-headedeuropean-wayuniversities-benefit; accessed 25/12/2017; FAZACKERLEY A (2017) ' 2 VCs on...how is Brexit impacting universities?' A. Fazackerley (The Guardian) 20/09/17 https://www.theguardian.com/higher-education-network/2017/sep/20/2vcs-onhow-is-brexit-impactinguniversities accessed 26/12/2017

${ }^{100}$ FAZACKERLEY A (2017) ‘ Universities abroad headhunting 95\% of UCL's top EU researchers, provost says' A. Fazacherley (The Guardian) 29/08/2017 https://www.theguardian.com/education/2017/aug/29/universities-abroad-headhunting-ucl-euresearchers-brexit accessed 25/12/2017

${ }^{101}$ HARDEE 'Central Exam' op. cit 102 Ibid

103 'Consultation Response and Our Decision on Next Steps' (April 2017) https://www.sra.org.uk/sra/consultations/solicitors-qualifying-examination.page

${ }^{104}$ BRADNEY, 'Dumbing down the law' op cit. 4

105 Ibid

106 '... there are not 253 responses listed, as the SRA claims. The document consisted on only 148 responses that address the feedback questions...' in HALL 'Notes on the SRA' op. cit 365

${ }^{107}$ BRADNEY, 'Dumbing down the law' op cit. 4-5
} 
'...the SQE will drive a prioritization of a limited kind of knowledge (and a particularly legal kind of knowledge) over the crucial elements that a high quality legal education could provide: understanding law in context; critical thinking; and innovation in thought about law.' 108

In conclusion, market pressures in the $\mathrm{HE}$ and in legal education indicates that many law teachers aspiration for a 'liberal legal education' may not be enough for our future law students; ideas of employability ${ }^{109}$ are quickly pushing law teachers into producing 'professional' law graduates, ${ }^{110}$ without having a 'proper' say on it.

\section{Conclusions.}

Law teachers are being affected by the changes introduced by TEF and the SQE. On the one hand, the metrics used in TEF sound foreign to University teachers that are more worried about the quality of the teaching and the learning of the students, than about employability or professionalism of their graduates. On the other hand, the SQE is already rattling universities, which are discussing which way their law schools should go in order to accommodate the type of law degree they will offer. Obviously, the idea of the SRA to envisage solicitors without a degree is being received with astonishment by many in legal education. In truth we do not yet know the real consequences of all these changes. Besides, there is no reason in principle, for these new pressures from the Government, the market, the TEF, the universities managements or the SQE, to be a total disadvantage for the future of legal education. What is certainly a problem is the fact that law teachers have not really had a say in all these changes, while it will be them on the ground dealing first-hand with a rapidly changing legal education landscape.

\section{Bibliography}

BACHAN R (2017), "Grade Inflation in UK Higher Education" in Studies in Higher Education, Vol 42, No 8, 2017, p. 1580-1600

BADLEY G (2016) “The Pragmatic University: A Feasible Utopia?" in Studies in Higher Education Vol 41 No 4, 2016, p. 631-641

BARON P and CORBIN L (2012), “Thinking like a Lawyer, acting like a Professional: Communities of Practice as a means of Challenging Orthodox Legal Education" in The law Teacher Vol 46 No 2, 2012) 100-109

\footnotetext{
${ }^{108}$ MOORHEAD R (2016) (professor of Law and professional ethics at UCL, in 'Lawyer Watch' 'My response to the SRA's proposals for and SQE, 28 feb 2016.https://lawyerwatch.wordpress.com/2016/02/28/my-response-to-the-sras-proposals-for-an-sqe/

109 TURNER J, BONE A and ASHTON J (2016), "Reasons why law students should have access to learning law through a skills-based approach (2016) in The Law Teacher DOI: 10,1080/030694001.2016.12017392.

${ }^{110}$ DAGILYTE E and COE P (2014) "Professionalism in Higher Education: Important not only for Lawyers" in The Law Teacher Vol 48 No 1, 2014, 33-42; BARON P and CORBIN L (2012), "Thinking like a Lawyer, acting like a Professional: Communities of Practice as a means of Challenging Orthodox Legal Education" in The law Teacher Vol 46 No 2, 2012) 100-109
} 
BLACKMORE P (2016) "Why Research Trumps Teaching and What can be Done About It" in Tackling Wicked Issues: Prestige and Employment in the Teaching Excellence Framework, ed, P Blackmore, R. Blackwell, and M Edmondson, 2016, Oxford. Occasional Paper 13, p 9-37

BOLSMANN C and MILLER D R (2008) "International student recruitment to universities in England: Discourse, rationales and globalisation" in Globalisation, Societies and Education Vol 6, 2008, p. 75-88

BUNCE L, BAIRD A and JONES S E (2017) "The Student-as-a-consumer Approach in higher education and Its Effect on Academic Performance" in Studies in Higher Education. Vol 42 No 11, 2017, p. 1958-1978

COLLINI S (2016) "Who are the Sponger Now?" in London Reviews of Books, Vol 38 No 2, 2016, p. 33-37

\section{CONSUMER RIGHTS ACT 2015.}

DEPARTMENT FOR BUSINESS INNOVATION AND SKILLS (White Paper 2016) 'Success as a Knowledge Economy: Teaching Excellence, Social Mobility and Students Choice' Published 16 May 2016

DEPARTMENT FOR BUSINESS INNOVATION AND SKILLS, (Green Paper) 2015. 'Fulfilling our potential: teaching excellence, social mobility and student choice' Published May 2015.

DEPARTMENT FOR EDUCATION, "Office for Students: regulatory framework for higher education” (Published 19 October 2017).

DAGILYTE E and COE P (2014) "Professionalism in Higher Education: Important not only for Lawyers" in The Law Teacher Vol 48 No 1, 2014, 33-42

DONNELLY C (2012) "Convergences and Divergences in educating Transnational Lawyers in The International Lawyer Vol 46, 2012, p. 627-634

FERGUSON L (2017) "Complicating the 'holy grail', simplifying the search: a critique of the conventional problematisation of social immobility in elite legal education and the profession" in The Law Teacher Vol 41 No 4, 2017, 377-400

FRANKHAM J (2017) "Employability and higher education: the follies of the 'Productivity Challenge' in the Teaching Excellence Framework in Journal of Education Policy, Vol 32 No 5, 2017 p. 628-641

FRY E, CREWE J and WAFEFORD (2013) "Using multiple choice questions to examine the content of the qualifying law degree accurately and reliably: the experience of the Qualified Lawyers Transfer Scheme" in The Law Teacher Vol 47 No 2, 2013 p. 234-242 
FRY E and WAKEFORD (2017) "Can we really have confidence in a centralised Solicitors Qualifying Exam? The example of the Qualified Lawyers Transfer Scheme" in The Law Teacher Vol 51 No 1, 2017, p. 98-103

FURNHAM A and PERTRIDES K (2010), 'The best university degrees to get a job' in Higher Education Review Vol 42, 2010, 50-62

HALL E (2017) "Notes on the SRA report of the consultation on the Solicitors qualifying Exam: 'Comment is free, but facts are sacred"' in The Law Teacher Vol 51 No 3, 2017, p. 364-372

HAYES A (2017) "The Teaching Excellence Framework in the United Kingdom: An Opportunity to Include International Students as 'Equals'?" in Journal of Studies in International Education Vol 21 No 5, 2017, p. 483-497

HEANEY C and MACKENZIE H (2017) "The Teaching Excellence Framework: Perpetual Pedagogical control in Postwelfare Capitalism" in Compass: Journal of Learning and Teaching Vol 10 No 2, 2017, p. 1-14

HIGHER EDUCATION ACADEMY (Qualifications) in https://www.heacademy.ac.uk/individuals/fellowship/fellow

HIGHER EDUCATION AND RESEARCH ACT 2017

HUBBLE S, FOSTER , D Foster and BOLTON P (2016) 'Higher education and Research Bill' Briefing Paper No 7608 (Published 30 June 2016)

JACKSON D (2015) "Employability skill development in work-integrated learning: Barriers and best practice" in Studies in Higher Education Vol 40 No 2, 2015, 350-361

JACKSON N and McCONNELL (2017) "Academic Lawyers and the new Solicitors Qualifying Examination: What stands in the way of consensus ad idem? (unpublished in file with authors)

LETR: Setting Standards: the Future of Legal services education and Training Regulation in England and Wales' published in June 2013

LYNCH R and HENNESSY J (2017) "Learning to earn? The role of performance grades in higher education" in Studies in Higher Education Vol 42 No 9. 2017, p. 17501763

MILLER G E (1990) "The Assessment of Clinical Skills/Competence/Performance" in Academic Medicine Vol 65 No 9, 1990. P 63-67.

NEARY M (2016) “Teaching Excellence Framework: a critical response and an alternative future" in Journal of Contemporary European Research Vol 12 No 3, 2016, p. 690-695 
RIGG D (2013) "Embedding employability in Assessment: Searching for the balance between academic learning and skills development in law: A case study" in The Law Teacher Vol 47 No 3, 2013, 404-412

ROBINSON W and HILLI A (2016) “The English 'Teaching Excellence Framework' and Professionalising Teaching and Learning in Research-Intensive Universities: and Exploration of Opportunities, Challenges, Rewards and Values from a Recent Empirical Study' in Foro de Education, Vol 14 No 21, 2016, p. 151-165

SABRI D (2013) "Student evaluations of Teaching as 'Fact-Totems': The Case of the UK National Student Survey' in Sociological Research Online Vol18 No 4 (published 30 Nov 2013) http://www.socresonline.org.uk/18/4/15.html

SMITH G and SMITH T (2014) "Tackling Educational disadvantage by Area: continuity and Change to Urban Areas in England 1968-2014" in Oxford Review of Education Vol 40 No 6, 2014, p. 715-738

SOLICITORS REGULATION AUTHORITY 'A new route to qualification: the Solicitors Qualifying Examination’ (25 April 2017)

THOLEN G et al. (2016) "Higher Education, Graduate Skills and the Skills of Graduates: The Case of Graduates as Residential Sales Estate Agents" in British Educational Research Journal Vol 42 No 3, 2016, p. 508-523

TURNER J, BONE A and ASHTON J (2016), "Reasons why law students should have access to learning law through a skills-based approach (2016) in The Law Teacher DOI: $10,1080 / 030694001.2016 .12017392$.

TYMON A (2013) "The Student Perspective on Employability" in Studies in Higher Education, Vol 38 No 6, 2013,p. 841-856

WHICH? (2014) 'A Degree of Value: value for money from the student experience' (November 2014)

WOOD M and SU F (2017) "What makes an excellent lecturer? Academics' perspectives on the discourse of 'teaching excellence' in higher education" in Teaching in Higher Education Vol 22, No 4, 2017 p. 451-466

WOODALL T, HILLER A and RESNICK (2014) "Making Sense of Higher Education: Students as Consumers and the Value of the University Experience" in Studies in Higher education Vol 39 No1, 2014, p. 48-67

\section{Recursos en Red}

BOXALL M (2016) 'Higher Education White Paper: The Big Changes' Higher Education Network. The Guardian, 16 May 2016. https://www.theguardian.com/highereducation-network/2016/may/16/higher-education-white-paper-the-big-changes 
BRADNEY A (2016)“'Dumbing down the Law: The SRA proposals for Legal Training' in Politeia http://www.politeia.co.uk/wpcontent/Politeia\%20Documents/2016/Feb\%20-

\%20Dumbing\%20down\%20the\%20Law/'Dumbing\%20Down\%20the\%20Law'\%20Feb

\%202016.pdf accessed 29/12/2017

FAZACKERLEY A (2017) '2 VCs on...how is Brexit impacting universities?' (The Guardian) 20/09/17 https://www.theguardian.com/higher-educationnetwork/2017/sep/20/2ves-onhow-is-brexit-impacting-universities

HARDEE M (2016) 'Central Exam idea does not add up' the Law Society Gazette, 29/02/2016 https://www.lawgazette.co.uk/features/central-exam-idea-does-not-addup/5053909.article accessed 28/12/2017

HOLYROYD J and SAUL J, (2016) 'Will the Teaching Excellence Framework Be Sexist' the Guardian (4 April 2016) https://www.theguardian.com/higher-educationnetwork/2016/apr/04/will-the-teaching-excellence-framework-be-sexist

iSTOCK (2017)'Teaching excellence framework (TEF) results 2017 (22 June 2017) https://www.timeshighereducation.com/news/teaching-excellence-frinamework-tefresults-2017

MORGAN J (2017) 'Higher Education and Research Bill passed by UK Parliament ' (27 April 2017) The Times Higher Education. https://www.timeshighereducation.com/news/higher-education-and-research-billpassed-uk-parliament\#survey-answer

MORGAN J, (2015) 'Jo Johnson Under Fire for Calling some University Teaching Lamentable' The Times Higher education (8 December 2015) https://www.timeshighereducation.com/news/jo-johnson-under-fire-calling-someuniversity-teaching-lamentable

MOORHEAD R (2016) (Professor of Law and professional ethics at UCL, in 'Lawyer Watch' 'My response to the SRA's proposals for and SQE, (28 February 2016.) https://lawyerwatch.wordpress.com/2016/02/28/my-response-to-the-sras-proposals-foran-sqe/

PELLS R (2017) 'Elite UK universities found to be second-rate in new Government ratings' (21 June 2017), More than half of Russell Group institutions - traditionally considered to the best in the country - did not score top marks. http://www.independent.co.uk/news/education/education-news/top-uk-universityrankings-gold-silver-bronze-oxford-cambridge-tef-teaching-excellence-frameworknew-a7801681.html

WILSON L. (2017) 'A bad-tempered Brexit is a risky mover for universities' (The Guardian) 11/11/2017 https://www.theguardian.com/higher-educationnetwork/2017/oct/11/brexit-cool-headed-european-wayuniversities-benefit 